\title{
Social networks of the Italian mafia; the strong and weak parts
}

«Social networks of the Italian mafia; the strong and weak parts»

by Bariş Çayli

Source:

CEU Political Science Journal (CEU Political Science Journal), issue: 03 / 2010, pages: 382-412, on www.ceeol.com.

eBooks on Central, East and Southeast Europe

\section{Anatoly Marlenoof}

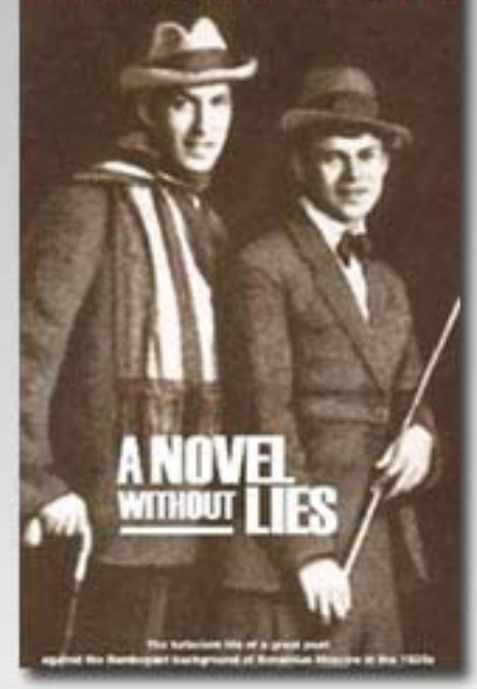

WWW.

\section{A Novel without Lies}

Glas New Russian Writing

Moscow, 2000, 192 p.

By Anatoly Mariengof

This is the story of an extraordinary friendship and an extraordinary poet seen through the prism of an extraordinary time and place - the upside-down world of Moscow just after the Revolution.

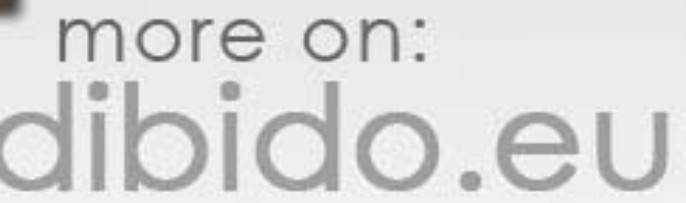


CEU Politic al Sc ience J oumal. Vol. 5, No. 3

\section{SOCIAL NETWORKS OF THE ITALIAN MAFIA THE STRONG AND WEAK PARTS}

Baris Cayli

University of Camerino

\section{Abstract}

In this paper, it is argued that a well-built, social network system has enabled the Mafia to reach a certain level of success through three main networks: members, local people, and politicians. I assert that the role of the executive power of the state has been partially supportive in this success. Moreover, this paper also concludes that to combat different Mafia groups, it is essential to know their strong and weak parts. Consequently, it is found that their well-built network system does not solely comprise of strong parts but that the weak parts also exist, albeit, that they have not yet played a defective role in the resolution of the Mafia. Therefore, this paper suggests that the illustration of both the strong and weak parts of these networks can have prominent and assisting role in the combat against the Mafia phenomenon in the future, either by strengthening the weak parts or by weakening the strong parts of its networks.

Keywords: Mafia, social network analysis

\section{Introduction}

The mafia phenomenon in Italy has been discussed widely from sociological, economical, psychological, etymological and political points of view whereas the social network system of the mafia from the approach of closed networks has not taken its place in the literature. Therefore, this paper aims to focus on the social network system of the different Mafia associations so as to fill the gap in the mafia studies. I need to mention the name of the prosecutor, Giovanni Falcone, who was murdered in 1992 by Sicilian Mafia (Cosa Nostra) as the source of inspiration of this 


\section{CEU Politic al Sc ience J oumal. Vol. 5, No. 3}

paper through his words about the Mafia: ${ }^{1}$ "We have to learn to think about the methods of Cosa Nostra calmly and with an open mind." ${ }^{2}$ Hopefully, this paper shows a distinctive analysis on how different Mafia groups have built their methods through up-todate networks, reaching a certain level of success. The main aim of this paper is not to show how to combat the Mafia by using its networks but to examine how they built their networks and illustrating the strong and weak parts of these networks in order to assist the fight against the Mafia.

In the first section, the paper emphasizes the theoretical and methodological reasoning of the paper. The paper highlights the social networks application to organized crimes, and finally, it explains the differential organizations theory of Matsueda ${ }^{3}$, before taking a further step and commencing the network analysis of organized crime in Italy.

In the second part, the notion is regarded firstly with the members of the Italian Mafia associations. This is necessary to comprehend what kind of formation they have, how they gain new members and build a system of recruitment, the importance of leadership, and their communicative and descriptive type of relationship. Moreover, pentito (Mafioso who collaborates with the judicial authorities) is explained as a concept of the weak part of these networks. The open and closed network system of Matsueda ${ }^{4}$ is used to define their network system after gaining a new member and in altering the type of relationship among the members.

In the third section, the main topic will be Italian Mafia groups' infiltration into the local people, how they have dominated the people in the local regions, and subordinated them on behalf of their own targets. To make the argument clear, the historical link

$1 \quad$ Mafia is used as a term to refer to Italian organized crime. Different mafia groups Cosa Nostra (Sicily), the Camorra (Campania), the 'Ndrangheta (Calabria), and the Sacra Corona Unita (Apuglia).

2 Diego Gambetta, "The Sicilian Mafia," Five Books, 6 October 2009, 6.

3 Ross L. Matsueda, "Differential social organization, collective action and crime," Crime, Law, and Social Change 46 (2006): 3-33. 
CEU Politic al Sc ience J oumal. Vol. 5, No. 3

of the Mafia groups in rural and urban regions based on the economic, sociological, and cultural facts of these regions are presented.

In the fourth section, Mafia groups' network with the politicians is the main concern of this part. In this section, the corrupted politicians and different Mafia groups' relationships are broadly described. In the next step, my argument suggests that there has never been consistent and cooperative commitment among politicians from the ruling and opposition parties in the fight against the Mafia. Furthermore, I assert that it is easy to break the relationship between politicians and Mafia groups. By using Matsueda's two strong closed networks and a weak tie figure ${ }^{5}$, I define this relationship as weak tie of the two closed strong bonds: the Mafia groups and the politicians.

In the fifth and the last part, the executive power of the state is analyzed in the consideration of its (dys)functionality and (in)effectiveness in the judicial and administrative divisions of the state. This is the last section as it signals that the Mafia's success does not simply belong to the efforts of its members building their networks but to the promotional and supportive influence of the half-functional administrative and justice system of the Italian state.

\section{Matsueda'a Theory of Social Networks in the Evaluation of Mafia Groups in Italy}

Social networking theory has been prominent in many fields: social psychology, communications, political science, and so on. Apart from these fields, it has gained essential importance for the study of organized crime. Moreover, a network perspective can be appraised as a social, political, and economic structure as lasting prototypes of the relational bonds between the actors. ${ }^{6}$ Thus, the denouncing of these bonds has critical importance for better comprehension of the workings of organized crimes like the Mafia

$5 \quad$ Matsueda, "Differential social organization," 15.

6 Jeffrey Scott McIlwain, "Organized Crime: A Social Network Approach," Crime, Law \& Social Change: An International Journal 32 (Dec. 1999): 301-323. 
CEU Political Sc ience J oumal. Vol. 5, No. 3

groups in Italy, which have taken their power from social, political, and economic discourses.

It is argued that social networking is also observable in the underworld, in the system of organized crimes. ${ }^{7}$ In this social network of the Mafia, the communication networks have an essential place because social interactions are the main instruments of a social organization. ${ }^{8}$ In accordance with these communication networks, the argument has gained popularity which states that the Mafia's main network systems are subordinated by three facts: kinship, patronage, and friendship. ${ }^{9}$ Additionally, these relationships, which are huge in number and variety, should be latent; each situation ought to be considered under their particular needs. Therefore, they have been master in binding those individuals in a traditional society. Similar to this, "a social network was viewed as a field of interaction that had neither units nor boundaries. It was formed by ties of friendship, kinship, and acquaintance partly inherited and partly constructed by the person himself or herself." ${ }^{10}$ These kinships, friendships, and networking structures of the Mafia phenomenon in Italy will be examined in the next sections within its members, local people, and politicians.

The role of Matsueda's noteworthy study ${ }^{11}$ on social organization and crime in this paper cannot be denied. His work on differential social organizations, collective action and crime is significantly important because it illustrates the conceptualization of an organization in favor of, and against crime as collective behavior. His figures, which are related with open and closed social networks, and local bridges linking two distinct closed networks, have been influential on my interpretation of the Mafia's social networks within its members and politicians, respectively. Two main reasons explain the use of Matseueda's approach to

\footnotetext{
7 McIllwain, "Organized Crime: A Social Network Approach," 310.

8 Charles W. Morris, ed., Mind, Self, and Society, George Herbert Mead 1934, (Chicago: University of Chicago Press, 1968), 253.

9 Raimondo Catanzaro, Men of Respect: A Social History of the Sicilian Mafia, trans. R. Rosenthal, (New York: Free Press, 1992), 43.

10 Fortunata Piselli, "Communities, Places, and Social Networks," American Behavioral Scientist 50 (2007): 867-878. 
scrutinize my arguments; first, this is the most appropriate orientation for understanding the Mafia's complex relationship background in Italy because it prioritizes goal-focused organizations like the Mafia. Secondly, Matseueda prioritizes collective behavior, which is pivotal for the analysis of secretly bonded informal structures like the Mafia. Therefore, his theoretical framework sets the tone for this paper. Replication of Matsueda's figures while analyzing the social networks is the main methodological reasoning in the paper. Nonetheless, this paper will hopefully bridge the gap in the academic field of Mafia research, where no evaluations exists of the Mafia phenomenon in Italy that takes into account its social networks and relations with members, local people, and politicians all together.

\section{Italian Mafia and Its Members}

In this part, the regulation of the affairs of the Mafiosi in different Mafia groups and the network systems among their members are explored. Firstly, the importance of the concepts, which make these bonds stronger, is examined, and the meaning of these rules and conducts are evaluated from the point of view of different Mafia associations like the Sicilian Cosa Nostra (Our Affair), the Napolitan Camorra, and the Calabrian 'Ndrangheta (Society of Men of Honor). Secondly, there is a need to clarify the organizational structure of the members of the Mafia family so as to comprehend and examine all components of the network system among the Mafia members such as the leadership, and the talent of adjustability. Thirdly, the vital importance of instrumental friendship, secrecy, and trust are the main notions of this section while establishing these networks. Finally, how they increase their members and include them in their closed network system and further recruitment process are explained by using the open and closed network system of Matsueda ${ }^{12}$ in Figure 1. Even though the Mafia associations have been successful in building these networks for its members, the existing weak parts among members have been emerging as the pentiti, Mafiosi, who after being captured, collaborate with the justice system and violate the code of silence. They are defined 
CEU Politic al Sc ience J oumal. Vol. 5, No. 3

as collaboratori di giustizia (collaborators with justice). This weak part in their network system is examined in the second subsection, where the importance of their organizational structure, trust, and loyalty are explained.

Firstly, the bond among mafia members is defined in three basic concepts: conduct, rules, and trust. These concepts have a leading role in making close interpersonal relationships and have crucial importance for unification in attaining the goals of the Mafia. These relationships were labeled as a process for "idealization of Mafia phenomenon."13 This is because such an idealization would be indispensible for transferring feelings to the members of the Mafia associations in that they belong to an organization with certain types of ceremonies and norms. Thereby, these features are established in order to let the members feel themselves as 'man of honor'. Additionally, these structural rituals create very close formations based on strong trust among the members, which are prominent for the existence of their future. Furthermore, trust and close personal relationships are fundamental for the strength of their networks.

The struggle to be a family has significant importance for the different Mafia associations. From here, the concept of 'family' is the symbol of close relationships, secrecy, and trustworthiness as is expected of an ordinary family. Moreover, although blood kinship is a natural circumstance of an ordinary family, this is not always the case for different Mafia groups. For instance, formation of Mafia organizations, especially La Cosa Nostra, resembles a very large family, whose thousands of members are strongly bonded and secretly oriented. This is not preferable but demonstrates that having blood kinship is not indispensible. On the contrary, the Calabrian 'Ndrangheta does not illustrate any hierarchical structure like the La Cosa Nostra but embraces a cell-based approach and the importance of blood kinships are more observable. ${ }^{14}$ Despite the existence of the differential

13 Letizia Paoli, Mafia Brotherhoods, Organized Crime, Italian Style (New York: Oxford University Press, 2003), 89.

14 Christine Spolar, "New Mafia gains power in Italy, baffling law enforcement," Chicago,13 July 2008, in http://www.freep.com/apps/pbcs.dll/article?AID=/20080713/NEWS07/807130540 
CEU Politic al Sc ience J oumal. Vol. 5, No. 3

structural formations among different Mafia groups, they have corresponding points, such as the importance of secrecy, the perception of being a family (with or without blood kinship), and demonstrating loyalty.

Secondly, I argue that the organizational structure of the Mafia indicates differences among Mafia groups, but the same factor influencing contributions of the new members has not changed; this is the protection of the secrecy and building trust in order to reduce risks in the closed network system. The formation of the numbers of members, their kinship and territorial basement may vary from one type of Mafia group to another. For instance, the traditional Cosa Nostra is a male-dominated family structure ruled by a code of conduct for members forbidding them from sharing the secrets of their organization. ${ }^{15}$ Moreover, any disobedience may result with violence against the violator of the 'code of conduct.' Similarly, Sicily's Cosa Nostra and the Calabrian 'Ndrangheta are observed as typical representations of the Mafia, and each is composed of more than 90 clans or 'families.' Certainly the most powerful are the Cosa Nostra clans, which have some 3,200 members concentrated in western Sicily. ${ }^{16}$ The mainland counterpart to the Cosa Nostra is the 'Ndrangheta, whose homeland is in the southern Calabrian province of Reggio Calabria. Around 4,500 members are grouped into some 90 clans or cosche, "a Sicilian term for 'artichoke,' which is intended to symbolize their intense cohesion." ${ }^{17}$

Finally, while establishing the new closed network system, Mafia members use special phrases and choose new members to include in their organizational chart by considering the strategic professions of those people from whose expertise they will benefit. In its special secrecy, instrumental friendship becomes crucially important while knitting the Mafia's network system to establish its basis as it is vital in order to make their informal

15 Donald Ray Cressey, Theft of the Nation: The Structure and Operation of Organized. Crime in America (New York: Harper and Row, 1969), 114-119, 242.

16 Letizia Paoli, "Family Crises among the 'Man of Honor," Research et Society. Max Planck Research, 2 (2004) 58-59.

17 Paoli, "Family Crises among the 'Man of Honor," 59. 


\section{CEU Political Sc ience J oumal. Vol. 5, No. 3}

organization more powerful through enlarging their members with strong bonds and specific communication systems. Thus, the expressions 'Tell him that I sent you' or 'Go in my name' are used in the Mafia network as a way of communication. ${ }^{18}$ These phrases create special bonds, which lead to the production of the social networks described in a popular way as 'the friends of the friends.' (Figure-1)

Furthermore, when the notion is Mafia phenomenon, a distinction should be made between different Mafia groups because the Cosa Nostra and 'Ndrangheta mainly prefer new members for recruitment from their neighborhood or towns in southern Italy. ${ }^{19}$ Conversely, the Camorra illustrates different characteristics and can establish its networks outside of their family or town if the candidate has the potential to increase the effectiveness of the organization. ${ }^{20}$ Finally the biggest fourth Mafia group from Puglia, Sacra Corona Unita (United Sacred Crown), consists of three main layers hierarchically, but it is important to note that a member can graduate its stature in the organization through demonstrating violence. The formations for closed networks and connection among the members have crucial importance for the Sacra Corona Unita because the networking should be like a ring of a chain. ${ }^{21}$ Even though there are differences in the formation of different mafia groups, one common point is both crucial and indispensible. This is the creation of trust as a value and its importance for the targets of the Mafia. The utmost importance of trust comes from "an emergent property of the social system, as much as a personal attribute. Individuals are able to be trusting (and not merely gullible) because of the social norms and networks within which their actions are embedded."22 Trust has been established by the symbols and signs in the alteration of the Mafia's network system from an open to closed network in order to add new members to their organization. (Figure-1)

\footnotetext{
18 Catanzaro, Men of Respect: A Social History of the Sicilian Mafia, 54.

19 Paoli, Mafia Brotherhoods: Organized Crimes, Italian Style, 18-47.

20 Tom Behan, The Camorra (London: Routledge, 1996), 191

21 Antonio Nicaso and Lee Lamothe, Global Mafia; The New World Order of Organized Crime, (Toronto: McMillan, 1995), 69. 


\section{CEU Politic al Sc ience J oumal. Vol. 5, No. 3}

After the descriptive and normative formation of the Mafia members' network system, it is time to illustrate it through the open and closed network system of Matsueda. ${ }^{23} \mathrm{I}$ argue that the well-organized communication system of different Mafia groups has a leading role in the construction of well-working social networking. Clarity for this argument may be enhanced by focusing on the study of Matsueda. He states that "given common everyday knowledge of the way in which these structures operate, individuals can use the structures strategically, seeking out closed structures to increase control over members." $24 \mathrm{He}$ also added that in Figure $1 \mathrm{a}$, both $A$ and $B$ can have influence $C$, but that they can only do it independently and with the help of individual sanctions, developing trust, establishing norms, and the like. However, they cannot influence each other because of the lack of social ties. As in Figure $1 \mathrm{~b}$, after this network is established, a close network system is built so that $A^{\prime}, B^{\prime}$, and $C^{\prime}$ can influence each other by developing coordinated strategies, simultaneous sanctions, and similar rhetorical arguments. ${ }^{25}$

For the case of the Mafia system, while they are building their social networks for increasing their members and/or to solve the problems of their customers or to make cooperation with them, they effectively create a closed social network system through 'trust' and the famous phrase, 'tell him that you are friend of mine.' Thus, after establishing a network followed with requirements about efficiency, reliability, and trustworthiness, a new member in the Mafia structure can take his place in this closed social network. He is not in the open structure anymore, but in the closed structure, where he should now obey the Mafia 'rules'. Additionally, the other significant feature is the importance of stability in the closed groups, which is gained through strong ties among members with similar ideas and homogeneity. ${ }^{26}$ Thus, the creation of this strong closed network among its members

Matsueda, "Differential social organization, collective action and crime," 15.

Matsueda, "Differential social organization, collective action and crime," 14

Matsueda, "Differential social organization, collective action and crime," 13-14.

M. Granovetter, "The Strength of Weak Ties," American Journal of Sociology 78 (May 1973):1360- 
CEU Political Sc ience J oumal. Vol. 5, No. 3

has crucial magnitude in the targets of the Mafia thanks to the principles of solidarity and commitment. Despite differences in the structuring of Mafia associations, they all have the same common thread of trust and secrecy.

Figure 1. Replication of open and closed social networks

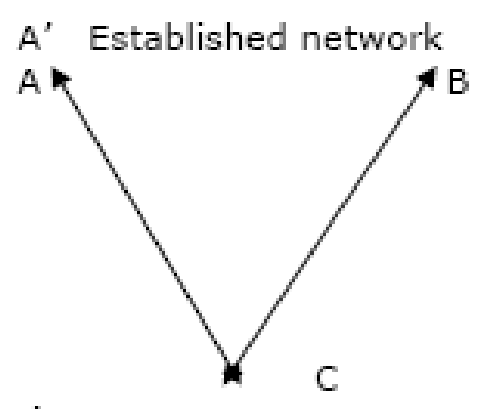

$C^{\prime}$ a. Open structure

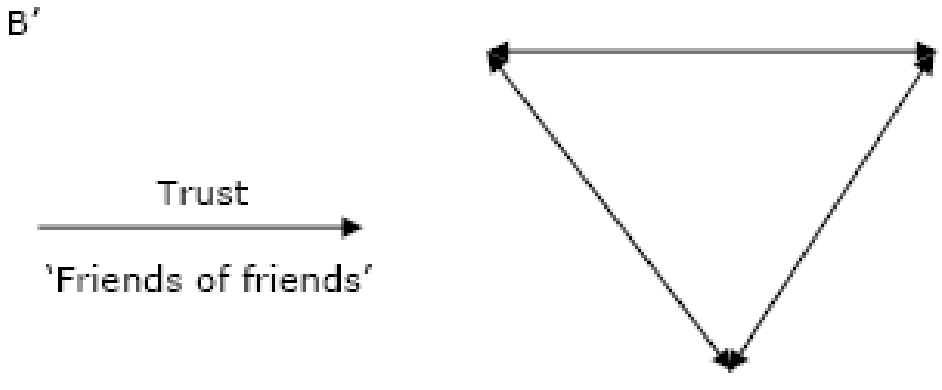

b. Closed structure

Source: Ross L. Matsueda, "Differential Social Organization, Collective Action and Crime," Crime, Law, and Social Change, 46 (2006), 14.

At this point, after examining the strengths of the Mafia while recruiting new membership, it remains important to stress the weaknesses of this network. Traditionally, secrecy is perceived as the most important criteria for membership. Contrary to this strict rule, Mafiosi have collaborated with police after capture on many occasions. Therefore, they violated these rules by becoming pentiti and sharing their secrets with the criminal justice system. Even Mafia leaders, through being pentiti, have violated these rules. Accordingly, such violations are a natural outcome of being arrested. This is because many Mafiosi prefer the favorable sentencing and privileges resulting from cooperating with the justice system. Thereby, the pentiti emerge as a significant weakness of different Mafia groups in Italy; the closed network system sustains its strength until the arrest of Mafiosi.

The first pentito in 1973, Leonardo Vitale, confessed significant secrets; albeit he did not receive sufficient attention for his confessions because of his mental problems. Apart from him, the most significant Mafioso turned pentito was Tommasso Buscetta 
CEU Politic al Sc ience J oumal. Vol. 5, No. 3

in the 1980s. He helped prosecutor Giovanni Falcone in the identification of the main channels that the Mafia operated. Especially after the Maxi Trial process during the mid 1980s, important Mafioso figures decided to be pentiti, such as Salvatore Contorno, Antinino Calderone, Giovanni Brusca, and so on. ${ }^{27}$ In addition to this, it has rarely been observed that such collaboration has been done with willingness when there is no possibility for arrest. Therefore, the consistency, solidarity, and loyalty to the Mafia are widely followed until arrest. In sum, the success of Mafia groups has been limited by pentiti. Confessions of Mafiosi have played as an essential role many times to resolve the networks of different Mafia groups.

\section{Italian Mafia and Local People}

This section aims to show the well-established communication networks of different Mafia groups, who take their territorial power from the relationships between Mafiosi and the locals. Throughout the section, territorial power of different Mafia groups is examined, which is a significant instrument to improve their influence over the local people. Firstly, Kohlberg's stages of moral reasoning will be applied to examine the bond between Mafia groups and local people. Secondly, I will argue that the weaknesses of these networks is again the local people, who have tried to show resistance against the Mafia by protesting the Mafia individually or establishing civil associations against its culture.

In this section, the main concern is adaptation of Kohlberg's ${ }^{28}$ and Piaget's stages of moral reasoning, ${ }^{29}$ which Matsueda references as well. ${ }^{30}$ This adaptation is focused on the relationships between the Mafia and local people on the one hand, and local people's reactions to these relationship bonds on the other. Firstly, it is necessary to elaborate Kohlberg's three

Martin Bull and James Newell, Italian Politics: Adjustment under Duress (Cambridge: Polity Pres, 2005), 111. 
levels and six stages of moral reasoning ${ }^{31}$ before making such a deep assessment. These six stages are based on the relationships between parents and children. I replicated the relationship between the child and parents to the relationship between Mafia and local people can be explained because of the similarity of those actors. The emergence of the Mafia from the late $19^{\text {th }}$ century, its changing situation over time and its authoritative and repressive role in the contemporary era may share the attitudes of the parents who demonstrate violence to their children along with an irresponsible attitude.

In the application of these principles, I examine the relationship between the locals and the historical Mafia, which exists in the towns of southern Italy and also in urban life in recent decades. I argue that since the middle of the $19^{\text {th }}$ century, stage 1 , stage 2 , and stage 3 occurred and that stage 4 occurred partially because the representative of the 'law and order' was not extensively identical with the Mafia but did come under state control, particularly after the Maxi-trial in 1986. Additionally, this stage has not been completed because of the existence of untrustworthiness in the region, and

\section{Table 1. Kohlberg's stages of moral reasoning}

Levels

Level 1 Pre-Conventional Morality

Level 2 Conventional Morality

Level 3 Post-Conventional Morality

Stage 1. Obedience and punishment orientation Stage 2. Individualism, exchange, and instrumentalism

Stage 3. Good relationships and mutual expectations

Stage 4. Law and order

Stage 5. Social contract and individual rights

Stage 6. Universal ethical principles

Source: Ross L. Matsueda, "Differential Social Organization, Collective Action, and Crime," Crime, Law, and Social Change, 46 (2006), 11. 
CEU Political Sc ience J oumal. Vol. 5, No. 3

less likely, because of locals' willingness to cooperate with the justice system, although this number has increased in recent decades. I assert that the Mafia phenomenon in Italy can widely be eradicated from the country after the end of stage 4, where all residents of the southern region and the entire country admit the supreme power of the culture of lawfulness and legality and have sufficient encouragement to stand against the Mafia. Postconventional morality is the last level in Italian society that ought to be reached, as it is a level of morality to rid the severe grip of the Mafia. Stages 5 and 6 in this last level may provide an ideal country, where the Mafia cannot invade the social, political, and economic arenas anymore by subordination of the local people physically, psychologically, and sociologically.

To fully comprehend such a relationship between local people and Mafia groups, I explain step-by-step how I raise these arguments through following three levels and six stages of Kohlberg's moral reasoning. The first stage - obedience and punishment - occurred with the emergence of the Mafia phenomenon in the middle of the $18^{\text {th }}$ century and was observed extensively until the period of the contemporary Mafia. Obeying the rules and not to be punished by the Mafiosi have been violated frequently in the last decade, but the fear of punishment by the Mafiosi is still effective in both rural areas and cities of Mezzogiorno - southern Italy. The local people witnessed brutality and violence publicly and observed clearly what happened to those who did not take Mafia threats seriously. These people paid for this opposition with their lives. Undoubtedly, an unequal relationship clearly exists between locals and the Mafiosi like the one that exists between a child and its authoritative parents. The Mafioso was the supreme authority over the local people.

The second stage - individualism and exchange - was accordingly the outcome of such oppression. Security has been one of the crucial elements in taking care of the community and society. With violence that puts your life in danger, consideration of long term societal benefits is not expected, so from an egocentric perspective, the security of your life becomes more significant. This is also the reason why the Mafia has become more powerful through the features of this network structure and that people 
valued it to ask for 'private protection. ${ }^{32}$ For these reasons, people preferred to obey 'omertà' -code of silence- with any issue relating to the Mafia. These first two stages would be labeled as preconventional morality reasoning, which emerged in the atmosphere of violence, embezzlement, and oppression, so egocentrism and personal benefits became the priority for the local people to survive under such a brutality.

The second level - conventional morality - has not been terminated completely yet. Although the third stage - good relationships and mutual expectation - has come to an end, the fourth stage - law and order - is still in the process of completion. If I start from the third stage, this process has almost been completed in the demonstration of people's attempts to consider the benefits of society as a whole through organizing civil societies and non-governmental initiatives against the Mafia. Aside from the anti-Mafia movement, local people have showed their cooperation by being pentiti and breaking the order of silence. In this regard, people who cooperated with authorities labeled their act as 'good' and the Mafia as 'bad'. Thus, they started improving 'good relationships' with the justice, police, and administrative organizations of the state. On the other hand, this optimistic panorama can be deceptive because local people should take the most crucial step, the fourth step, in the fight against the Mafia. The supreme power of rule of law and the benefits of society, which are based on legality, should be the main cornerstone in the fight against the Mafia. Unfortunately, such a decisive struggle has not been observed in the region. For instance, in Sicily, the majority of the people and local shops still pay pizzo, a protection racket. ${ }^{33}$ In sum, the completion of the fourth stage and establishing the pure mechanism of law and order in the region is significantly prominent to terminate the second level - conventional morality. The devastating history of the local people and the relationships with the Mafia should not

32 Diego Gambetta, The Sicilian Mafia The Business of Private Protection (Cambridge, MA: Harvard University Press, 1996), 3, 26-29.

33 Francesca Forno and Carina Gunnarson, "Everyday shopping to fight the Italian Mafia," in Michele Micheletti and Andrew S. McFarland eds., Creative Participation: Responsibility-Taking in the Political World, (Paradigm Publishers, Bolder, 2009), 101-110. 
be underestimated for the completion of the third step on a permanent basis. After the victory of the fourth stage, the last level is likely to be less challenging.

The last level - post-conventional morality - can only occur in the last steps of the fight if it becomes possible to eradicate the Mafia from the country completely. The fifth step - social contract and individual rights - may increase its importance on Italian citizens in an environment where they can enforce the political spectrum with mass social movements to ask for decisive and ad hoc policies, only associated with the social contract, whose particular characteristic recognizes the benefits of both individuals and society through anti-corruption, transparency, accountability, and matured democracy. Therefore, in the last step, it can be possible to talk about the universal values and ethics after taking account of the full consensus of the citizens' participation in this process. In the last place, after a significant victory has been gained against the Mafia, the remaining Mafiosi breaking away from their illegal and violent business so they may potentially turn towards these universal values and ethics. This argument has already found its echoes in the definition of social equilibrium of Putnam. The high levels of cooperation, trust, reciprocity, civic engagement and collective well-being are noted as the traits to define civic community. ${ }^{34}$ In this regard, attaining the last level depends on the establishment of these traits so as to be a recognized civic community who demonstrates consistent resistance against the Mafia.

Finally, a weakness also exists in the networks of the Mafiosi with the local people. Although this weak part has not been directly related to the success or failure of the Mafiosi, it has an indirect effect, which causes direct resistance from the local people to increase their voice against the subordination of the Mafia. It still remains difficult to declare that this weak part is strong enough to break all these networks of the different Mafia groups among the local people in today's Italy. But it contains in itself an opportunity for the future to demolish its networks when the resistance of the local people is extended and becomes powerful 
CEU Politic al Sc ience J oumal. Vol. 5, No. 3

enough to replace the culture of illegality with the culture of lawfulness.

The first strikes of this resistance appeared generally as individual reactions. For instance, Italian journalist Mauro de Mauro was kidnapped by the Mafia in 1970 when he tried to investigate a murder. ${ }^{35}$ Secondly, in 1978 the Cosa Nosta murdered Giuseppe Impastato, a significant anti-Mafia figure and political activist. He was born in a Mafia family but decided to fight against the Cosa Nostra and paid for it with his life. This was the striking proof that the Mafia brutally reacts when their networks and 'respectability' are targeted. Mauro de Mauro and Giuseppe Impastato were not the only victims of this resistance. Libero Grassi was a businessman who refused to pay pizzo, extortion money, and he advertised in the newspaper by calling on other businessmen not to pay racket to the Mafia. He was murdered in 1991. ${ }^{36}$ Furthermore, the tragic assassinations of the prosecutors Giovanne Falcone and Paolo Borsellino in 1992 had been the limit for the civil society to illustrate their reaction in a well planned and intensive way. All these individual attempts to seek the Mafia's dirty works and to fight against it lead to attaining societal reactions against the Mafia. Thereby, Libera was established in 1995 as a non-profit civil society aimed at fighting against the Mafia and giving self-esteem and support to the local people who show their resistance to it. This resistance has been institutionalized with over 1000 associations in the country, but it is still far from declaring that victory in this fight. Apart from Libera, many other civil society organizations were established to align themselves in the fight against the Mafia. What is more, this struggle should not be underestimated because of its potential to devastate local networks of the Mafiosi. For instance, in 2009, over 100,000 people gathered in Naples and marched against the Mafia. ${ }^{37}$ Even though dominance of the different Mafia groups is

35 Peter Popham, "Revealed: How Story of Mafia Plot to Launch Coup Cost Reporter His Life," The Independent, (June 19, 2005) [database on-line]; Available at:

http://www.independent.co.uk/news/world/europe/revealed-how-story-of-mafia-plot-to-launch-

coup-cost-reporter-his-life-494619.html

36 Dino Paternostro, "Libero grassi, martire civile," La Sicilia, August 30, 2009. 34.

37 Cristiano Corvino, "Tens of Thousand March in Naples against the Mafia," Reuters (21 March, 2009), [database on-line]; Available at: http://www.reuters.com/article/idUSTRE52K0Z220090321 
CEU Political Sc ience J oumal. Vol. 5, No. 3

still clearly observable in southern Italy, these popular protests are the weak part of the networks of the Mafiosi on local people who demonstrated clear reluctance to react against the Mafia for dozens of years.

Therefore, the success of the Mafia's influence on local people depends on many factors, such as the socio-historical situation of the region, cultural patriarchy, economic factors, the lack of the existence of a responsible state mind in the region, and a combination of all these paradigms. All these reasons need to be counted in this complex sociological concentration of the Mafia. Further, if we do not consider their well-calculated social network system and influence on the local people through these networks, any explanation is far from complete. Indeed, I assert that the power of this network comes from the strong bond between local people and authoritative manner of the Mafiosi. This also makes it challenging to prevent the Mafia's extended power, but the recent civil society efforts to eradicate the Mafia provide hope for the future and become the weak link of the Mafia's networks within the local people.

\section{Italian Mafia and Politicians}

In this section, I argue that the relationship between Mafiosi and politicians is one based on mutual benefits. The polls are given as an example to indicate intersected points where the Mafiosi and politicians correspond. Secondly, I conclude that the contextual events are influential in the evaluation of the collusion between the politicians and the Mafia from the perspective of decaying corrupted institutions. Finally, I assert that the sensitive bond between politicians and the Mafia is the main concern. The argument concentrates on the sensitivity of this bond as the outcome of the existing weak link between politicians and Mafiosi, which is expecially vulnerable due to the lack of emotional attachment. I will illustrate my argument with Figure 2 through Matseuda's weak tie of two strong closed networks. This deficiency of the emotional bond has also been the weak part of their successfully renowned history and mutual benefits, which is hard to discover but easy to break after its emergence. 
I argue that the symbiotic relationship between Mafiosi and politicians dominates their networks, taking into account the benefits of both parts. In this context, the commencement of this strong relationship should be perceived as a historical phenomenon whose roots were established on the symbiotic bond of each party in the criminal world because of its appetite for profits. ${ }^{38}$ This bond managed to extend to the entire political system, especially after the emergence of the Mafia in the $19^{\text {th }}$ century. In the meantime, this poison seems to have had an aphrodisiac-like effect in the spectrum of the cooperative Mafiapolitical nexus. Moreover, the pure dependency of politicians on the territorial power of the Mafia was more apparent during elections because winning a local or parliamentary election is almost unachievable without accepting Mafia protection. ${ }^{39}$ The Mafia had another arm in the Senate and Chamber of the Duties to use for their ends, which were mostly related with the political and administrative handicaps they faced. ${ }^{40}$ Thus, this system, which consists of real power groups, may have the potential to deeply affect political life by using its influence on people's decisions during the elections. ${ }^{41}$ In sum, the baseline of these mutual relationships was determined by the obsessive power holders between the Mafiosi and politicians. The polls also can give clues about the rising power of the Mafia and it becomes clear after the emergence of Silvia Berlusconi in the political arena in the first half of the 1990s. That was interpreted as a 'vicious circle': "More than a few corrupt Christian Democrats and Socialists who were voted out in the anti-Mafia climate of the 1990s are now finding their way back into office - most of them as candidates for the right-wing conservative camp of Silvio Berlusconi's governing coalition." 42 In the last elections, by presenting the unified list under the slogan of Casa della Libertà

\footnotetext{
38 Pierre Tramblay and Carlo Morselli, "Patterns in Criminal Achievement; Wilson and Abrahamse Revisitied" Criminology 68 (May 2000): 659-663.

39 Gaetona Mosca, "Che Cosa è la Mafia," in G. Mosca, Partiti a sindacati nelle crisi del regime parlamentare (Bari: Laterza, [1900] 1949), 243.

40 Catanzaro, Men of Respect, 54,142, 201.

41 Salvatore F. Romano, Storia Della Mafia (Salerno: Arnoldo Mondadori, 1966), 172.

42 Paoli, "Family Crises among the 'Man of Honor," 62.
} 
CEU Politic al Sc ience J oumal. Vol. 5, No. 3

('House of Liberty') more essentially, they gained extensive success by winning 60 direct seats. ${ }^{43}$

Political institutions, contextual events and even international settings may help to shed light on the relationship between politicians and Mafiosi. For instance, Propaganda Due (P2) was a secret Masonic lodge whose members are comprised not only of journalists and people from business and industry but also of members of parliament like Prime Minister Silvio Berlusconi. ${ }^{44}$ P2 influenced taking over Corriere della Sera, a prominent Italian newspaper, ${ }^{45}$ misleading police in the investigation of the 1980 Bologna Massacre which resulted with death of 85 people. ${ }^{46}$ Secondly, Gladio, the secret organization, was influential in Italy in creating resistance against communism with the collaboration of the CIA and other Mafia associations in Italy. The collusion of the Gladio with the politicians and the underworld have structured the political spectrum after post-war Italy and was used as yet another justification for mafia-politicians collusion. ${ }^{47}$ Thirdly, Prime Minister Aldo Moro was killed in 1978 by a communist organization, Red Brigades, and it is argued that he was not saved by the Italian government because of fear that Moro could confess about Gladio. ${ }^{48}$ Moreover, one of the most significant examples was the operation of 'Clean Hands'. During this operation, 3,200 suspected bureaucrats and politicians were convicted between 1992 and 2002. ${ }^{49}$ Unfortunately, even before these corruptions, Mafia dominance in politics was expressed and approved by state funded organizations like the Ant-Mafia Commission which was established in $1962 .^{50}$ Thus, it is clear

\footnotetext{
43 Paoli, "Family Crises among the 'Man of Honor," 63.

44 Jones Tobias, The Dark Heart of Italy (London: Faber \& Faber, 2003), 186-187.

45 Paul Gingsborg, Italy and Its Discontents; Family, Civil Society, State: 1980 - 2001, (New York: Palgrave McMillan, 2003), 144-148.

46

47 Bull and Newell, Italian Politics: Adjustment under Duress (Cambridge: Polity Pres, 2005$), 100$.

48 Par Hubert Artus, "Pourquoi le pouvoir italien a lâché Aldo Moro, exécuté en 1978," Rue8, 6 February 2008, available at: http://www.rue89.com/cabinet-de-lecture/pourquoi-le-pouvoir-italien-a-lachealdo-moro-execute-en-1978

49 Maffei and Betsos, "Crime and Criminal Policy in Italy," 474.

50 René Seindal, Mafia Money and Politics in Sicily 1950-1997 (Denmark: Museum Tusculanum Press, 1998), 50.
} 
that other secret organizations accompanied the Mafia in the second half of the $20^{\text {th }}$ century after the manipulation of Italian social and political life by the Mafia during the first half of the 20th century. It is remarkable to stress that the state demonstrated the capacity to counter attack on the Mafia and secret organizations. In this respect, Maxiprocesso, Maxi Trial, was held between 1984 and 1986. As a result, hundreds of Mafiosi were put behind bars. The destruction of the secret organization like P2 and Gladio and the operations of Clean Hands occurred during the 1990s. In recent years, famous Mafia Godfathers like Bernardo Provenzano and Salvotore Russo were captured. These developments have created the perception that the fight against the Mafia has gradually been more successful. But, the confession of the son of the former mayor of Palermo, Massimo Ciancimino, caused the public to doubt the anti-Mafia struggle of Berlusconi government. He declared that Forza Italia, led by Berlusconi, was the result of negotiations between the state and Cosa Nostra, Sicilian Mafia. ${ }^{51}$

Therefore, in order to make these complex networks more observable systematically, there is a need to elaborate and illustrate the network relations between politicians and the Mafia on a figure. According to Matsueda, as shown in Figure 2, closed network groups can establish weak ties with other closed groups to have benefits from information flows, novel ideas, more so, since all these exchanges are coming from a set of comparatively dissimilar groups. ${ }^{52}$ In addition to this, the weak ties between different closed networks provide group members chances to increase the likelihood of group members who organize into social movements. ${ }^{53}$ For the case of the Mafia, the weak tie between $\mathrm{C}$ and $\mathrm{E}$ in Figure 2 represents the mutual outcomes of this network between the Mafia and politicians and bureaucracy in the state. Furthermore, it is argued that resource mobilization theory through the utilization of the maximum benefits of the

51 "Forza Italia Born from Mafia Talks," Ansa, 8 February 2010, available at http://www.ansa.it/web/notizie/rubriche/english/2010/02/08/visualizza_new.html_1701529485.html

52 Matsueda, "Differential Social Organization, " 15.

53 Mark Granovetter, "The Strength of Weak Ties," American Journal of Sociology 78(May 1973):

$1360-1380$ 
CEU Politic al Sc ience J oumal. Vol. 5, No. 3

rational actors by using their social networks and political opportunities is significant with collective action. ${ }^{54}$ It remains important to stress that in order to design such collective action, civic engagement is less likely to be observed with the lack of trust in politicians. ${ }^{55}$ With hindsight it is clear that this is the road taken by the political institutions and regional governments in order to make cooperation with the Mafia.

Besides, the significance of the accordance for the objectives and the struggle to employ them to make their targets attainable has become the remarkable argument for the criminal world. ${ }^{56}$ This argument is also operative for the case of the Mafia. On the one hand, the Mafia worked for politicians to help them win elections, or to make their positions stronger and support bureaucrats through bribes. On the other hand, its position and businesses became more and more secure under the protective umbrella of the state bureaucrats and politicians. This mutual network structure between the Mafia and the dark side of the state is one of the essential proofs as to why the vicious cycle of the Mafia has not been terminated to date. Their meeting point to serve their mutual benefits makes this bond stronger but not unbreakable. Furthermore, this bond is weak when we compare two groups' network structures, which are based on rules, laws, and regulations for both the informal organization of the Mafia and the formal organization of the state. Therefore, since this bond between $\mathrm{C}$ and $\mathrm{E}$ (see Figure 2) is based on mutual material benefits but not strong emotional bonds, this tie can be defined as paradoxically weak but strong in terms of resisting showing their relationships explicitly. Moreover, the indispensable relationship between the Mafia and politicians is vulnerable when their benefits are at risk. Therefore, in this regard, this tie is also weak but breaking it is difficult since this

\footnotetext{
54 Robert D. Benford and David A. Snow, "Framing Processes and Social Movements: An Overview and Assessment," Annual Review of Sociology 26 (2000), 611-639.

$55 \quad$ Putnam, Making Democracy Work, 172.

56 Edwin H. Sutherland, "Development of the Theory," in E. H. Sutherland, On. Analyzing Crime (Chicago: University of Chicago Press, [1942] (1973), 13-29.
} 
CEU Political Sc ience J oumal. Vol. 5, No. 3

symbiotic relationship of the two closed group networks has a very little strategic gap that can harm their bonds.

\section{Figure 2. Replication of the Local Bridge (weak tie) linking two distinct closed networks}

Mafia's closed network system

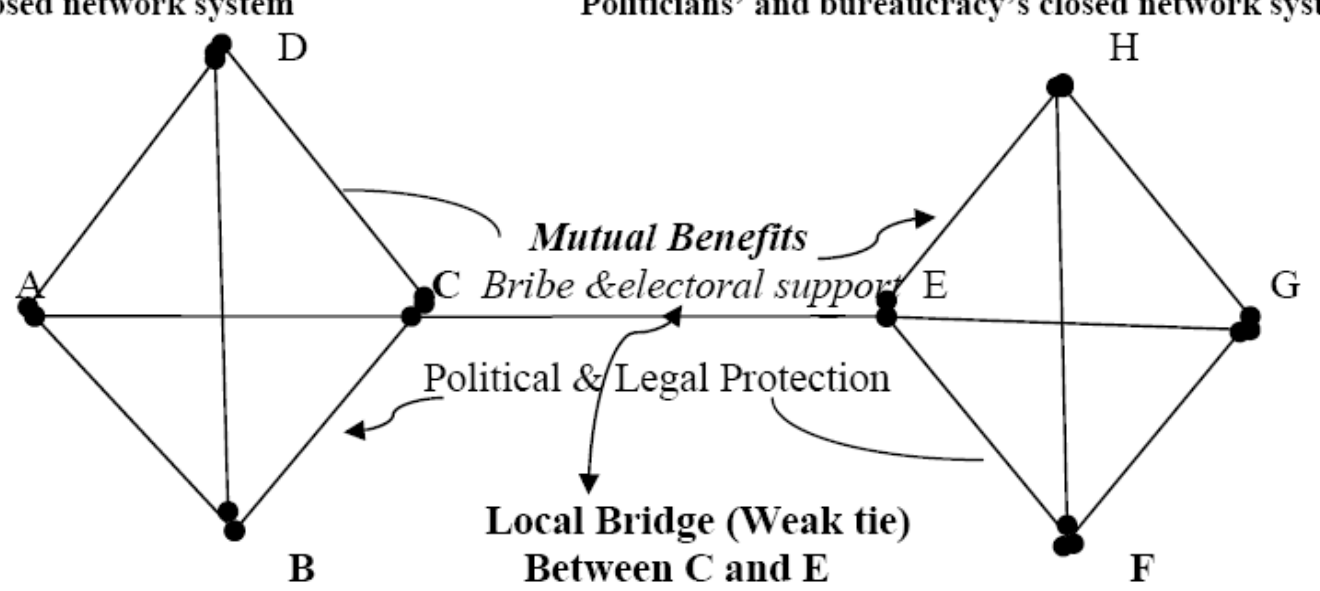

Group 1 Strongly tied

Group 2 Strongly tied

Source: Ross L. Matsueda "Differential Social Organization, Collective Action, and Crime." Crime, Law, and Social Change 46:3-33, p. 15, 2006.)

\section{Italian Mafia and Executive Power of the State}

In this section, the role of the executive power of the state in its relationships with different Mafia groups is examined. I argue that the two most critical elements, dysfunctionality and ineffectiveness of the judiciary and administration systems of the state, fostered the power of the different Mafia groups. Even in the last decade, the performance of these institutions has gradually increased, but is far from filling the gap that has existed since Italian unification in 1861. First I elaborate on the role of the executive power of the state from the concepts of violence and power. I then examine the reliability of state institutions in the country. Finally, I scrutinize today's political arena in the country and the latest developments in this field.

Firstly, it is necessary to make the connection between how the Mafia became successful in the absence of state power and their background knowledge of society. Further, the state's ineffectiveness in promoting territorial order made the Mafia's 


\section{CEU Politic al Sc ience J oumal. Vol. 5, No. 3}

infrastructure more profitable and serviceable. In the meantime, the origins of the Mafia's emergence provided them with good knowledge of the society's reaction, formation, and attitudes. Thus, the strength of the Mafia's enduring position is related with their strong social networks, which were established in the consideration of the historical process and in mastering adaptability and power orientation. Using these features, the Mafia gained benefits for their ends through cooperating with politicians and legal authorities in the lines of the mutual outcomes.

Today's Italian administrative and justice system are in serious decline in terms of efficiency and reliability, which makes the Mafia's position more durable. The decrease in public confidence in the justice system creates a dangerous atmosphere in the country. ${ }^{57}$ In support of this argument, "Italian criminal courts seem unable to deal with the backlog of cases. Further, a 2006 pardon law intended to put an end to the endemic overcrowding of state prisons, has further undermined public confidence in the state's ability to bring justice to criminal matters." ${ }^{58}$ In fact, urgent reform in the Italian justice and administrative system is not an issue of recent years but one that stems from the historical ineffectiveness of the justice system, which has lead to the empowering of the Mafia through the socio-cultural and historical structure of the Mezzogiorno (southern Italy) since the mid $-19^{\text {th }}$ century. This appropriate atmosphere for the Mafia provides them the best conditions to make their bonds stronger and to increase their power and 'order' over the society.

Thus, although all these statements draw a pessimistic portrait of the fight against Mafia, its elimination from society and state units is not unattainable. The severe hit to destroy the Mafia's power and capacity should be breaking up its networks, especially the ones established with politicians. In recent years, it has been found that "organized crime is negatively related to police performance and the rule of law and positively related to 
CEU Politic al Sc ience J oumal. Vol. 5, No. 3

grand corruption." 59 In this context, if organized crime is more powerful, legislation, policy-making, and legal rulings may not be in the general interest of the public but to benefit the few. ${ }^{60}$ Moreover, the importance of the value network cannot be denied by the essential struggle of the police through following goods, knowledge, and the connections between actors. ${ }^{61}$ According to this approach, the cooperation of legislative officers, analysts, and investigating officers may provide crucial support to resolve the organized crime networks. Above all, in order to break up the strong networks of the Mafia, what we need is a functional and effective justice system, police power, and more operative ways to increase local people's cooperation with the state. The final essential requirements are to remove grand corruption and increase transparency in public administration and reinforcing the executive power of the state with the aim of constituting consolidated anti-mafia policies.

\section{Conclusion}

The examination of the Italian Mafia groups from the perspective of social networks tries to fill a significant void in academia by being the first study of the strong and weak parts of these networks within three main actors: members, local people, and politicians. There is certainly much to be said about the importance of Matsueda's work because his differential social organization sheds light on the strong and weak parts of the Mafia. Although the main aim of this paper is not to show how to resolve these networks, illustrating these strategic strengths and weaknesses of their networks may play an important role in simplifying the methodology of future research regarding the fight against the Mafia phenomenon in Italy.

59 Van J. Dijk, "Mafia Markers: Assessing Organized Crime and its Impacts upon Societies," Trends in Organized Crime 10 (2007), 51.

60 Dijk, "Mafia Markers," 478.

61 Peter Gottschalk, "Value Configurations in Organized Crime," Journal of Policing and Society 19 (Jan. 2009), 47-57. 
The findings of this paper hopefully fill the gap in the interdisciplinary field of social networks and organized crime structuring in Italy. These findings declare that the complex structure of the Mafia organization among its members, local people, and politicians has a strong historical background that affects the contemporary situation. Making the strong parts weaker and using the weaker parts to demolish the strong ones of its networks appear as a crucial strategy to be focused on it. Thus, this study's findings announce firstly the strong parts of its networks among the members of the Mafia which are leadership factors; their solidarity and commitment until being arrested; the rules, codes, and norms in the organizations; adjusting capacity to the new situations by making their organizational structure tighter or looser according to this change in closed network structural formation. Secondly, the strong part of its networks established with the local people can be summed up as the domination of the people through violence; acting as the informal state in their territories; severe punishment of people who violate their rules; creating an untrustworthy atmosphere to settle private protection; and reference to the 'man of honor' or 'respectable person' phrases to legitimize their brutal authority. Finally, the politicians who collaborate with Mafia groups in exchange for electoral support and bribery in order to get legal and political protection summarize the strong parts of its networks. Therefore, another outcome of the relationship has been the enrichment of the each actor's benefit in the system of corruption.

Apart from the strenghts of these networks, the weaknesses provide an opening change for eradicating these networks. The first weakness in the network is the violation of their closed network system even by the leaders of organizations as being pentiti and collaborators with the justice system. Cooperation with justice and state organs and violating the basic rules after arrest emerge as significant outcomes. When there is no other alternative to save themselves, Mafiosi prioritize their personal benefits rather than the benefits of their Mafia family and friends while cooperating with the state. Secondly, the weakness of the networks of local people is the increasing willingness to resist the dominance of Mafia groups in the region, albeit this resistance is 
still in the minority. Civil society groups, non-governmental institutions and personal endeavors may potentially lead to a decrease in Mafiosi extortion in the long-term. Even though this struggle is not directly related with the networks system of the Mafiosi, it is the outcome of past acts of violence of the Mafiosi against locals who demonstrated resistance against the Mafiosi. Finally, the weak part in the network with politicians is their bond, which is solely based on material benefit and the lack of any emotional link. This weak tie between two strong closed network systems is a breaking point when a threat appears and puts the benefits of each part in danger.

The second part of the paper focuses on the role of the state and it bears emphasis that the state constituted the catalyst in fostering both the emergence and empowering of the Mafia because of its malfunction in the administrative and justice system. The decaying trust in the politicians has made the fight to eradicate the Mafia from political and social speres of the country quite difficult. At this point, it is worth noting that the lack of such a counter position from the state power for demolishing the Italian Mafia has made the humus of the Mafia's culture of illegality more resilient over time. If different Mafia associations still exist and are invincible in Italy today, albeit in the late efforts of the state, their well-built and designed social network system has an essential place in this success story of the Mafia, but their achievement cannot solely be explained by the power of their networks. Ineffective and corrupt state institutions along with the cooperation of some politicians with the Mafia and the half functional criminal justice system have made the Mafia stronger and more overwhelming. Even though there have been combative periods to demolish the Mafia, with some fruitful results, these periods could never be followed up with corresponding and durable cooperation, including all state institutions and politicians to destroy the Mafia permanently. In contrast, the Mafia has always found another solution to cope with any threat or danger by adjusting themselves to the new situations through their disciplined and synchronized structure. Putting it differently, because of such a boomerang effect in the fight against the Mafia, the silence of the different Mafia groups in the last decade can create a butterfly effect for the Mafia groups 
CEU Political Sc ience J oumal. Vol. 5, No. 3

to increase their power and seek new, illegal, and profitable markets with a less risky atmosphere by strengthening its weak parts.

All of this amounts to saying that both strong and weak parts of the social networks of the Mafia should be followed by a welldesigned systematic plan in the contribution of all stakeholders in society against the Mafia. At this point, it would be reductive not to mention the limitations of this study in order to construct the combat plan with the aim of getting rid of the Mafia's grip. Even though the Mafia phenomenon has been studied for more than a century, the subject contains obstacles because of the criminal secrecy of the underworld. In this study, as it commonly occurs in other mafia studies, the limitations are firstly based on the confessions of the captured Mafiosi. It is doubtful how much those confessions can be trusted. Secondly, there may be other strong and weak parts of the social networks of the Mafia groups which are not mentioned in this study. Thirdly, this study aims to focus on the Mafia networks' from the point view of actor-based approach rather than target-based approach so it classified networks of the Mafia within local people, politicians and its members who are significant national actors in terms of emergence of the Mafia and gaining power over those networks. Despite these concerns, the limitations of this study provide opportunities for future studies of the Mafia as well. Firstly, the opportunity arises from taking a social networks approach as the point of origin and seeking the targets of the Mafiosi throughout those networks. Secondly, this paper is limited to one country and it does not examine the international dimension of the subject. Further research endeavors can take into account international social networks of the Mafia and their influence past, present and future. 
CEU Political Sc ience J oumal. Vol. 5, No. 3

\section{Bibliography}

Artus, Par Hubert. "Pourquoi le pouvoir italien a lâché Aldo Moro, exécuté en 1978," Rue8, 6 February 2008, available at: http://www.rue89.com/cabinet-de-lecture/pourquoi-lepouvoir-italien-a-lache-aldo-moro-execute-en-1978

Behan, Tom. The Camorra. Routledge: London, 1996. Benford, Robert D. and Snow, David A. "Framing Processes and Social Movements: An Overview and Assessment," Annual Review of Sociology 26 (2000): 611-639.

Block, Alan. East side, West side. Organizing Crime in New York; 1930-1950 New Brunswick, N.J, London: Transaction Books, 1999.

Blok, A. The Mafia of a Sicilian village, 1860-1960. New York: Harper \& Row., 1974.

Bull, Martin and Newell, James. Italian Politics: Adjustment under Duress, Polity Press, Cambridge, 2005.

Catanzaro, R. Men of Respect: A Social History of the Sicilian Mafia, trans. R. Rosenthal. New York: Free Press, 1992. Corvino, Cristiano."Tens of Thousand March in Naples against the Mafia," Reuters, (21 March, 2009. Available at: http://www.reuters.com/article/idUSTRE52K0Z220090321 Cressey, D.R. Theft of the Nation: The Structure and Operation of Organized. Crime in America. New York: Harper and Row, 1969.

Duggan, Christopher, Fascism and the Mafia. New Haven and London: Yale University Press, 1989.

Fabbrini, S. "The Transformation of Italian Democracy," Bulletin of Italian Politics 1 (2009): 29-47.

Falcone, Giovanni. Men of Honour: The Truth about the Mafia. London: Fourth Estate, 1992.

Forno, Francesca and Gunnarson, Carina."Everyday Shopping to Fight the Italian Mafia," in Creative

Participation: Responsibility-taking in the Political World, ed. Michele Micheletti and Andrew McFarland. Bolder, Paradigm Publishers, 2009.

"Forza Italia Born from Mafia Talks," Ansa, 8 February 2010, available 
CEU Politic al Sc ience J oumal. Vol. 5, No. 3

http://www.ansa.it/web/notizie/rubriche/english/20 10/02/08/visualizza_new.html_1 701529485.html Gambetta, Diego. The Sicilian Mafia; The Business of Private Protection. Cambridge MA: Harvard University Press, 1993.

$2009,6$.

. "The Sicilian Mafia," Five Books, 6 October

Gingsborg, Paul. Italy and Its Discontents; Family, Civil Society, State: 1980 - 2001. New York: Palgrave McMillan, 2003.

Gottschalk, Peter. "Value Configurations in Organized Crime," Journal of Policing and Society 19 (Jan. 2009): 4757.

Granovetter, M. "The Strength of Weak Ties," American Journal of Sociology 78 (May 1973): 1360-1380.

Hess, Henner. Mafia, Bari: Laterza, 1970.

Lupo, Salvatore, "Uutopia totalitaria del fascismo (1918-42)," in La Sicilia, ed. M. Aymard and G. Giarrizzo. Torino: Giulio Einaudi Editore, 1987.

Kohlberg, L. The Philosophy of Moral Development. Harper \& Row, San Francisco, 1981.

Maffei, Stefano and Merzagora Betsos, Isabella. "Crime and Criminal Policy in Italy: Tradition and Modernity in a Troubled Country," European Journal of Criminology 4 (Apr. 2007): 461-482.

Madno, Giuseppe C., L'opposizione mafiosa. Mafia politica stato liberale. Palermo: Flaccovio, 1986.

Matsueda, Ross L. "Differential Social Organization, Collective Action, and Crime," Crime, Law, and Social Change 46 (2006): 3-33.

McIllwain, Jeffrey Scott. "Organized Crime: A Social Network Approach," Crime, Law \& Social Change: An International Journal 32( April 2006): 301-323.

Mosca, Gaetona. "Che Cosa è la Mafia," in G. Mosca, Partiti a sindacati nelle crisi del regime parlamentare. Bari: Laterza, [1900] 1949.

Nicaso, Antonio and Lamothe, Lee. Global Mafia; The New World Order of Organized Crime. Toronto: McMillan, 1995.

Paoli, Letizia. Mafia Brotherhoods: Organized Crime, Italian Style, New York: Oxford University Press, 2003. 
CEU Political Sc ience J oumal. Vol. 5, No. 3

."Family Crises among the 'Man of Honor," Research

et Society. Max Planck Research, 2 (2004): 58-62

Paternostro. Dino, "Libero grassi, martire civile," La Sicilia, 30 August 2009, 34.

Piaget, J. The Child's Conception of the World. Routledge and Kegan Paul, London, 1928.

Piselli, Fortunata. "Communities, Places, and Social Networks" American Behavioral Scientist 50 (2007): 867-878.

Popham, Peter. "Revealed: How Story of Mafia Plot to Launch Coup Cost Reporter His Life," The Independent. 19 July 2005. Available at

http://www.independent.co.uk/news/world/europe/revealed-howstory-of-mafia-plot-to-launch-coup-cost-reporter-his-life494619.html

Putnam, Robert D., Making Democracy Work. Princeton: Princeton Universitiy Press, 1993.

Romano, Salvatore F. Storia Della Mafia. Salerno: Arnoldo Mondadori, 1966.

Seindal, René. Mafia Money and Politics in Sicily 1950-1997, Denmark: Museum Tusculanum Press, 1998.

Santino, Umberto. "Guida al processo Andreotti," Citt d'utopia (November, 1995)

Schneider, Jane, and Peter T. Schneider. Culture and Political Economy in Western Sicily. NewYork: Academic Press, 1976.

Stille, Alexander. Excellent Cadavers : The Mafia and the Death of the First Italian Republic. $\quad$ 1st ed. New York: Pantheon Books, 1995.

Spolar, Christine. "New Mafia gains power in Italy, baffling law enforcement," Mafia-News, 2008. Database online, available at:

http://www.mafia-news.com/new-mafia-gains-power-in-italybaffling-law-enforcement/

Tarrow, Sidney G., Peasant Communism in Southern Italy. New Haven and London: Yale University Press, 1967.

Tobias, Jones. The Dark Heart of Italy, London: Faber \& Faber, 2003.

Turone, Giuliano, Il delitto di associazione mafiosa.Milano: Giuffré, 1995. 
CEU Political Sc ience J oumal. Vol. 5, No. 3

Sutherland, E. H. "Development of the Theory," In E. H. Sutherland, On. Analyzing Crime. Chicago: University of Chicago Press, [1942] 1973.

Tremblay, Pierre and Carlo Morselli. "Patterns in Criminal Achievement: Wilson and Abrahamse Revisited," Criminology 38 (May 2000): 659-663.

Van Dijk, J. "Mafia Markers: Assessing Organized Crime and its Impacts upon Societies," Trends in Organized Crime 10 (2007): 39-56. 